\title{
In Vitro Propagation of Coryphantha macromeris
}

\section{R.H. Smith ${ }^{1}$, P.J. Burdick, J. Anthony, and A.A. Reilley \\ Department of Soil and Crop Sciences, Texas A\&M University, College Station, TX 77843}

Additional index words tissue culture, micropropagation, Cactaceae

Cacti are asexually propagated by offsets and cuttings or sexually via seeds (Johnson and Emino, 1979a). However, many species are slow-growing and do not produce offsets. Seeds are sometimes difficult to obtain (Mauseth, 1977) and seedlings are susceptible to damping-off (Mauseth, 1979). As onefourth of all cacti native to the United States are rare or in danger of extinction (Benson, 1977), in vitro propagation of cacti is an attractive alternative for multiplication and maintenance of valuable germplasm.

Callus induction (Ault and Blackmon, 1987; Johnson and Emino, 1979a; Mauseth, 1977; Steinhart, 1962) and in vitro growth regulation (Mauseth and Halperin, 1975; Minocha and Mehra, 1974) have been investigated for some cacti species. Johnson and Emino (1979a, 1979b) reported successful in vitro propagation of Mammillaria elongata DC., Opuntia polyacantha Haw. P. and Hylocereus calcaratus (A. Berger) Britt $\&$ Rose. However, each cactus species required a different auxin: cytokinin balance for shoot induction (Johnson and Emino, 1979b). Ault and Blackmon (1987) reported in vitro shoot proliferation from Ferocactus acanthodes (Lemaire) Britt. \& Rose. We describe an in vitro propagation method for Coryphantha macromeris (Engelm.) Lem. from callus culture.

Seeds were surface sterilized in $1.05 \%$ (w/ v) $\mathrm{NaOCl}$ for 10 rein, rinsed in sterile water, and then aseptically germinated on Murashige and Skoog (1962) (MS) inorganic salts, $\mathrm{pH} 5.9$, and solidified with 6 g Bacto agar/ liter. All cultures were maintained under a $24 \mu \mathrm{mol} \cdot \mathrm{s}^{-1} \cdot \mathrm{m}^{-2}$ light intensity (Sylvania Grow Lux wide spectrum fluorescent bulbs) for $16 \mathrm{~h}$ daily at $26 \pm 3 \mathrm{C}$.

Shoot explants from the aseptically grown seedlings were cultured on MS medium supplemented with (per liter) $0.4 \mathrm{mg}$ thiamine.HCI, 100 i-inositol, $20 \mathrm{~g}$ sucrose, 44

Received for publication 27 June 1990. Paper no. 22676, Texas Agricultural Experiment Station. The cost of publishing this paper was defrayed in part by the payment of page charges. Under postal regulations, this paper therefore must be hereby marked advertisement solely to indicate this fact.

'Author to whom reprint requests should be sent. $\mu \mathrm{M} N$-(phenylmethyl) -1 $H$-purine-6-amine (BA), and $0.5 \mu \mathrm{M} 2,4 \sim$ dichlorophenoxyacetic acid $(2,4-\mathrm{D})$ at $\mathrm{pH} 5.7$ for callus proliferation. Callus grew in 3 to 4 weeks and was maintained through subculture on the identical medium. This callus has been subcultured for $>4$ years. Shoot formation occurred sporadically on this callus (Fig. 1A). For shoot multiplication, 6- to 8-mm-diameter callus pieces with an average weight of $0.41 \mathrm{~g}$ were subculture on identical medium without plant growth regulators. In 6 weeks the callus diameter had increased to 20 to 40 $\mathrm{mm}$ and averaged $4.45 \mathrm{~g}$. Multiple shoots (Fig. 1B) developed after 6 to 8 weeks and as many as 20 shoots formed per culture tube. Shoot cultures have been subculture at 4to 8-week intervals on medium free of plant growth regulators for $>2$ years.

Root initiation occurred on shoots in the multiplication medium at a low frequency (36/190, 19\%). For enhanced rooting, shoots were separated and cultured on one-half strength MS inorganic salts plus (per liter) $0.4 \mathrm{mg}$ thiamine $\cdot \mathrm{HCl}, 20 \mathrm{~g}$ sucrose, and 1.5 g Gelrite (Schweizerhall, N.J.). Initial rooting experiments compared Gelrite-solidified medium to vermiculite moistened with the rooting medium (MS salts, thiamine $\cdot \mathrm{HCl}$ and sucrose), both in $25 \times 150$-mm culture tubes. Roots formed in 4 weeks but at a low frequency on the agar medium (4/20 shoots rooted). After 20 weeks, $90 \%$ of the shoots in both treatments $(18 / 20$ gelrite, and 36/40 vermiculite) had rooted. Rooted shoots were transferred to $40 \mathrm{ml}$ of a 1 peat : 1 vermiculite $(\mathrm{v} / \mathrm{v})$ potting mixture contained in 55$\mathrm{ml}$ plastic pots. Pots were placed in a plastic tray covered with plastic wrap for $\approx 2$ weeks to gradually harden off the plants. The plants were kept in the culture room (24 $\mu \mathrm{mol} \cdot \mathrm{s}^{-1} \cdot \mathrm{m}^{2}$ ) light intensity $16 \mathrm{~h}$ daily at $26 \pm 3 \mathrm{C}$ ) and $55 \%$ survived.

Rooting efficiency was examined in $25 \times$ 150-mm culture tubes containing $25 \mathrm{ml} \mathrm{MS}$ medium and in Magenta GA-7 vessels (Magenta Corp., Chicago) with $10 \mathrm{ml} \mathrm{MS} \mathrm{me-}$ dium. Of shoots placed in test tubes, $64 \%$ (36/56) formed roots after 12 weeks and $90 \%$ after 20 weeks. Ten milliliters of medium that covered the bottom of Magenta vessels desiccated during the culture period of 8

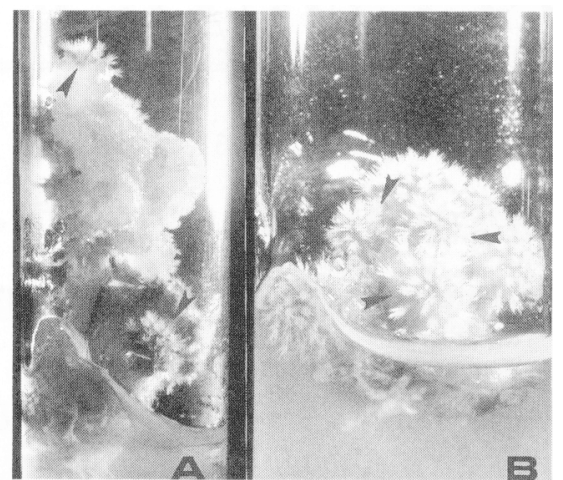

Fig. 1. (A) Callus cultures of C. macromeris on the callus induction medium, $0.8 \times$. Some shoot formation (arrows) occurred on this medium. (B) Multiple shoot development (arrows) from C. macromeris callus cultured on medium lacking plant growth regulators, $1 .-3 \times$.

weeks. Drying of the agar enhanced root formation and 73\% (203/279) of the shoots from three experiments formed roots after 7 to 8 weeks. Survival of these rooted shoots in pots was $64 \%(36 / 56)$ in one trial, but $28 \%$ (26/42) in another trial because of a fungal infection.

This study demonstrated that in vitro shoot proliferation can easily be used to maintain germplasm of $C$. marcromeris in culture and to rapidly produce many plants.

\section{Literature Cited}

Ault, J.R. and W.J. Blackmon. 1987. In vitro propagation of Ferocactus acanthodes (Cactaceae). HortScience 22:126-127.

Benson, L. 1977. Preservation of cacti and management of the ecosystem, p. 283-300. In: G.T. Prance and T.S. Elias (eds.). Extinction is forever. New York Bet. Garden, N.Y.

Johnson, J.L. and E.R. Emino. 1979a. In vitro propagation of Mammillaria elongata. HortScience 14:605-606.

Johnson, J.L. and E.R. Emino. 1979b. Tissue culture propagation in the Cactaceae. Cactus \& Succ. J. (U. S.) 51:275-277.

Mauseth, J.D. 1977. Cactus tissue culture: a potential method of propagation. Cactus \& Succ. J. (U.S.) 49:80-81.

Mauseth, J.D. 1979. A new method for the propagation of cacti: sterile culture of axillary buds. Cactus \& Succ. J. (U. S.) 51:186-187.

Mauseth, J.D. and W. Halperin. 1975. Hormonal control of organogenesis in Opuntia polyacantha (Cactaceae). Amer. J. Bet. 62:869-877.

Minocha, S.C. and P.N. Mehra. 1974. Nutritional and morphogenetic investigations on callus cultures of Neomammillaria prolifera Miller (Cactaceae). Amer. J. Bet. 61:168-173.

Murashige, T. and F. Skoog. 1962. A revised medium for rapid growth and bioassays with tobacco tissue cultures. Physiol. Plant. 15:474497.

Steinhart, C.E. 1962. Tissue culture of a cactus. Science 137:545-546. 